UDC 33.021[657.411.005.5]

DOI: $10.15673 /$ fie.v12i2.1737

Kuprina $\mathbf{N}$.

Ph.D., Associate Professor

Department of Accounting and Auditing

E-mail:k.natali_@ukr.net

ORCID ID: 0000-0003-4645-545X

\author{
Markova T. \\ Ph.D., Associate Professor \\ Department of Accounting and Auditing \\ E-mail: markova.tetiana17@gmail.com \\ ORCID ID: 0000-0002-9437-2635
}

Stupnytska M.

The student of the fourth grade of Management, Marketing and Logistics Faculty

Odessa National Academy of Food Technologies

Kanatna str., 112, Odesa, Ukraine, 65039

E-mail: marino4ka036@gmail.com

ORCID ID: 0000-0003-0736-6411

\title{
ANALYSIS OF THE OWN CAPITAL OF UKRAINIAN ENTERPRISES AND FEATURES OF ITS MANAGEMENT IN THE CONDITIONS OF THE NEW ECONOMY OF THE GLOBAL MARKET
}

The article notes that the concept of "equity" in the studied literature is considered from the standpoint of economic, accounting, legal and financial management. The analysis of the dynamics and structure of the balance sheet of enterprises by type of economic activity of Ukraine for six years shows an increase in the balance sheet currency by $90 \%$. An analysis of the statistical dynamics of changes in the structure of equity of enterprises by type of economic activity of Ukraine over six years shows that since 2014 the structure of registered capital, additional capital has changed dramatically and there is uncovered loss, which has a negative tendency to increase. The low value of retained earnings and the emergence of losses justifies the need for an effective system of equity management, because it is due to this component there is the increase in equity and expansion of economic activity. Tasks for effective management of own capital of enterprises have been defined. The stages of the system of effective equity management of enterprises have been proposed.

Key words: equity, structure of equity of enterprises by types of economic activity of Ukraine, analysis, management, balance.

This work is licensed under a Creative Commons Attribution 4.0 International License http://creativecommons.org/licenses/by/4.0/

Statement of the problem and its connection with important scientific and practical tasks. The emergence of the form of ownership as a mechanism of integration and concentration of capital allowed the emergence of equity to satisfy the interests of its owners, as the shortage of own funds hampered sole proprietorship. Thus, today the company's equity is an important component (basis and foundation) among the sources of resources of the enterprise, which contributes to productive activities, ie ensures financial and economic independence of the enterprise from borrowed funds and provides financial stability, and affects the competitiveness of the enterprise and efficiency of its functioning. It is impossible to start a business without equity, because the newly created company needs a certain amount to legalize it in the executive branch, order a seal, open bank accounts in national currency, purchase non-current and current assets, hire qualified specialists, develop strategic plans and independently determine by the enterprise of the directions of its development. In addition, in the context of globalization processes taking place in the economy of Ukraine with unfavorable trends in the reproduc- tion of equity, typical for most domestic enterprises (loss, insolvency, low efficiency and turnover of capital, high accounts payable, high financial risk, etc.), require analysis of the structural relationship, identification of factors of negative trends and future changes in the system of financial management of the enterprise. Equity management is especially relevant for domestic enterprises in modern conditions, given the limited external sources of funding, reduced profits.

The analysis of the latest publications on the problem. Issues of equity analysis and features of its management in the professional literature are represented by the following scientists: Blank I.O., Slavyuk R.A., Mishchuk E.V., Epifanova I.Y., Dryga S.G., Oleksandrenko I. V., Rudyka V.I., Berenda N.I., Kharchuk S.A., Ponomarenko N.M., Kharchenko N.V., Silakova G.V., Petukhova O.M., Lyubar O.O., Kalinina A.V., Dekhtyar N.A. and others, whose achievements are important enough for their practical application. However, the dynamics of Ukraine's equity efficiency requires a clear analysis and identification of factors that slow down its effective reproduction and development. 
Forming of the aims of the research. The purpose of this article is to study the statistical structural trend of equity formation of enterprises by types of economic activity of Ukraine, features of the equity management system of the enterprise in a changing market, development of optimization and ways to improve it, identify factors that increase or decrease equity, which is the basis for the effective operation of the enterprise, which is formed and used to obtain and increase profits.

Giving an account of the main results and their substantiation. The study of the essence of equity of the enterprise by various scholars shows its consideration from four positions: economic, legal, financial management and accounting, because in political economy capital is a factor of production, sometimes identified with the means of production, from a legal point of view equity is seen as a reflection of rights of owners, in financial management - its effective management, and from an accounting point of view, capital is the difference between the assets of the entity and its liabilities. Kalinina A.V., Dekhtyar N.A. believe that "equity - is a set of financial resources of the entity, owned by him and created at the expense of the owners of the enterprise or as a result of its efficient management, the presence of which ensures the financial stability of the enterprise, ie the possibility and continuity of economic activity and reducing its financial risk" [1].

We share the opinion of R.A. Slavyuk that "eq- uity is the core of financial and economic activities of all joint stock companies. Without its sufficient size it is impossible to obtain profitable activities of enterprises. The efficiency of economic activity of any joint-stock company is determined by the processes of formation and use of its own capital. Equity characterizes the value of financial resources of the enterprise, which belong to it on the property rights and are used to form a certain part of the assets, which are called "net assets". That is, equity is constantly owned by the company and is at its disposal "[2].

Note that equity consists of two parts: registered and unregistered capital. The registered can include share capital, and the unregistered - additional, reserve (insurance), unpaid, withdrawn capital and retained earnings (uncovered loss). A study of the statistical dynamics of changes in the structure of equity of enterprises by type of economic activity of Ukraine for six years (Fig. 1) shows that since 2014 the structure of registered capital, additional capital has changed dramatically and there is uncovered loss, which has a negative tendency to increase. Such changes in the formation of equity of enterprises by type of economic activity of Ukraine were affected by the economic crisis of 2014. Given the low value of retained earnings, there the relevance of effective equity management becomes clear, because it is due to this component is an increase in equity and expansion of economic activity.

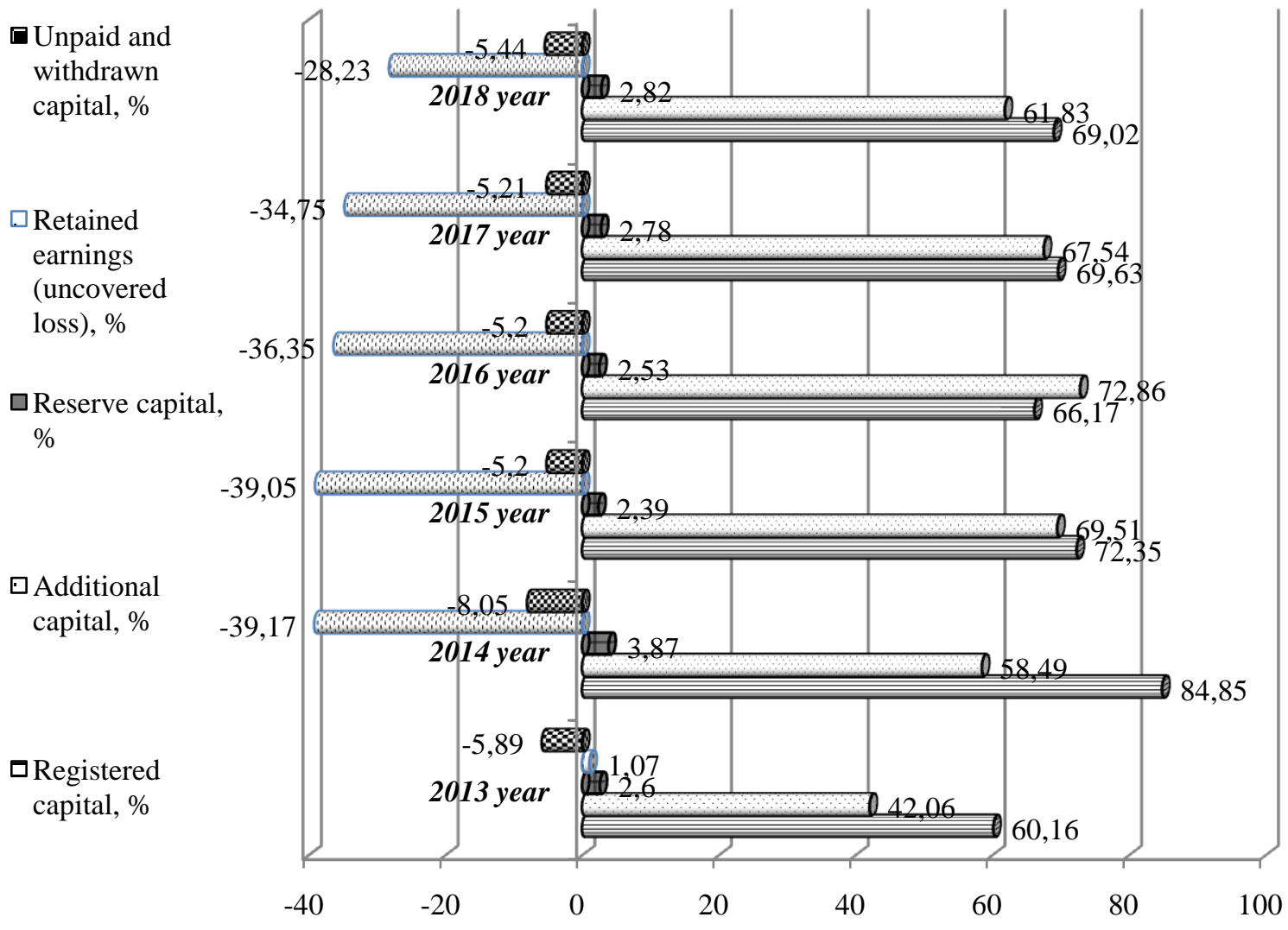

Fig. 1. Dynamics of change in the structure of equity of enterprises by type of economic activity of Ukraine for 2013-2018*

*compiled by author based on sources [3] 
Thus, the analysis of the dynamics and structure of the balance sheet of enterprises by type of economic activity of Ukraine for six years (Table 1) shows an increase in the balance sheet currency by $90 \%$. The asset structure of the balance sheet of enterprises by type of economic activity of Ukraine has a stable ratio of current and non-current assets. Note that the share of non-current assets is $42-49 \%$, and non-current assets - $50-57 \%$.
Analysis of the structure of liabilities of the balance sheet of enterprises by type of economic activity of Ukraine shows that most of the current liabilities and provisions are from $47 \%$ to $59 \%$. Equity ranks second in the structure of the balance sheet and its share ranges from $24 \%$ to $34 \%$. Long-term liabilities and provisions cover up to $22 \%$ of the sources of assets of Ukrainian enterprises.

Table 1

Dynamics and structure of the balance of enterprises by types of economic activity of Ukraine for 2013-2018*

\begin{tabular}{|c|c|c|c|c|c|c|c|c|c|c|c|}
\hline \multirow{2}{*}{ Years } & \multicolumn{3}{|c|}{ Non-current assets } & \multicolumn{3}{|c|}{ Current assets } & \multicolumn{3}{|c|}{$\begin{array}{l}\text { Non-current assets and } \\
\text { disposal groups } \\
\end{array}$} & \multirow{2}{*}{\multicolumn{2}{|c|}{$\begin{array}{c}\text { Balance } \\
\text { thousand UAH }\end{array}$}} \\
\hline & thousand UAH & \multicolumn{2}{|c|}{$\%$} & \multicolumn{3}{|r|}{$\%$} & \multicolumn{2}{|c|}{$\begin{array}{l}\text { thousand } \\
\text { UAH }\end{array}$} & \multirow[t]{2}{*}{$\%$} & & \\
\hline \multicolumn{11}{|c|}{ ASSETS } & \\
\hline 2013 & 2639813169,3 & \multicolumn{2}{|c|}{46,21} & \multirow{2}{*}{\multicolumn{2}{|c|}{\begin{tabular}{|l|}
3069041563,6 \\
3271954021.3
\end{tabular}}} & \multirow{2}{*}{$\begin{array}{l}53,73 \\
5458\end{array}$} & \multicolumn{2}{|c|}{3420077,2} & 0,06 & \multicolumn{2}{|c|}{5712274810,1} \\
\hline 2014 & 2717620345,2 & \multicolumn{2}{|c|}{45,34} & & & & 46912 & & 0,08 & \multicolumn{2}{|c|}{5994265571,9} \\
\hline 2015 & 3960148877,9 & \multicolumn{2}{|c|}{49,05} & \multicolumn{2}{|c|}{4108602679,3} & 50,89 & \multicolumn{2}{|c|}{5031819,2} & 0,06 & \multicolumn{2}{|c|}{8073783376,4} \\
\hline 2016 & 4212813136,0 & \multicolumn{2}{|c|}{42,16} & \multicolumn{2}{|c|}{5772816523,9} & 57,78 & \multicolumn{2}{|c|}{6161551,7} & 0,06 & \multicolumn{2}{|c|}{9991791211,6} \\
\hline 2017 & 4303282789,2 & \multicolumn{2}{|c|}{43,20} & \multicolumn{2}{|c|}{5650817419,4} & 56,72 & & 0,08 & \multirow{2}{*}{\multicolumn{2}{|c|}{$\frac{9961779060,4}{108780506280}$}} \\
\hline 2018 & 4584315559,2 & 42 , & & \multicolumn{2}{|c|}{6285066560,4} & 57,78 & \multicolumn{2}{|c|}{8668508,4} & 0,08 & & \\
\hline & & & & & & IABIL & TIES & & & & \\
\hline Years & Equity & & & $\begin{array}{l}\text { ong-term lia } \\
\text { and provis }\end{array}$ & $\begin{array}{l}\text { ilities } \\
\text { nns }\end{array}$ & & $\begin{array}{l}\text { ent liabi } \\
\text { provisi }\end{array}$ & $\begin{array}{l}\text { ities } \\
\text { ns }\end{array}$ & $\begin{array}{r}\text { Liabilities } \\
\text { non-current } \\
\text { disposal gro } \\
\text { asset value o } \\
\text { pension }\end{array}$ & $\begin{array}{l}\text { ed to } \\
\text { s and } \\
\text { nd net } \\
\text { l-state } \\
\text { ls }\end{array}$ & lan \\
\hline & $\begin{array}{l}\text { thousand } \\
\text { UAH }\end{array}$ & $\%$ & & $\begin{array}{l}\text { thousand } \\
\text { UAH }\end{array}$ & $\%$ & & $\begin{array}{l}\text { and } \\
\mathrm{H}\end{array}$ & $\%$ & $\begin{array}{l}\text { thousand } \\
\text { UAH }\end{array}$ & $\%$ & $\begin{array}{l}\text { thousand } \\
\text { UAH }\end{array}$ \\
\hline 2013 & 1950374877,8 & 34,14 & & 70722135,4 & 18,74 & 26893 & 88170,9 & 47,08 & 1839626,0 & 0,03 & 5712274810,1 \\
\hline 2014 & 1480658001,0 & 24,70 & & 59925672,9 & 22,69 & 31512 & 3038,8 & 52,57 & 2428859,2 & 0,04 & 5994265571,9 \\
\hline 2015 & 2288741367,5 & 28,35 & & 68157966,0 & 20,66 & 41149 & 3221,6 & 50,97 & 1980821,3 & 0,02 & 8073783376,4 \\
\hline 2016 & 2445803708,0 & 24,48 & & 96870653,7 & 16,98 & 58466 & 38669,2 & 58,51 & 2428180,7 & 0,02 & 9991791211,6 \\
\hline 2017 & 2458527641,4 & 24,68 & & 30977377,4 & 17,38 & 57695 & 88995,9 & 57,92 & 2735045,7 & 0,03 & 9961779060,4 \\
\hline 2018 & 2708576887,7 & 24,90 & & 57580586,2 & 16,16 & 64085 & 53734,3 & 58,91 & 3339419,8 & 0,03 & 10878050628,0 \\
\hline
\end{tabular}

The study showed that such proportions could not but affect the efficiency of enterprise equity management by type of economic activity of Ukraine. And each owner has a task to develop and improve the management system of equity, to find leverage to "increase (decrease) equity, the order of formation of reserve (insurance) capi- tal, the order of formation and use of additional capital, methods of reinvestment in corporate rights, taxation operations that involve an increase (decrease) in registered capital, etc." [4], as the coefficient of financial independence ranges from $24.48 \%$ to $34.14 \%$ (Fig. 2), while the regulatory value of this figure must be more than $50 \%$.

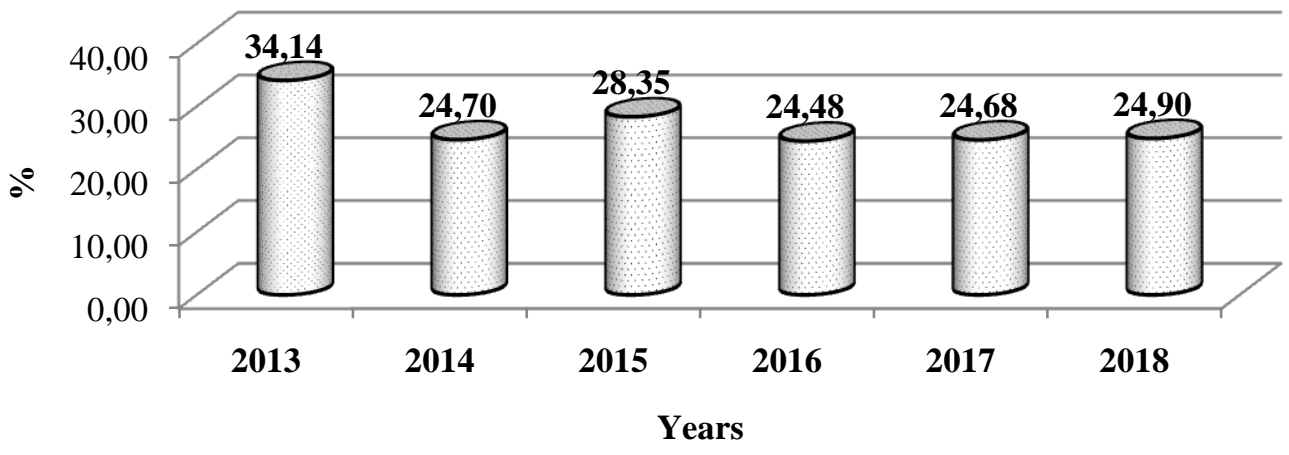

Fig. 2. Dynamics of financial independence of enterprises by types of economic activity of Ukraine for 2013-2018*

*compiled by author based on sources [3] 
According to the experience of domestic enterprises, it is an effective system of effective equity management that protects interests, minimizes risks and demonstrates the effect of the use of invested funds is a prerequisite for those enterprises that are interested and preferred by investors.

Thus, the consequences of the economic crisis are limited own financial resources of the enterprise, difficulties of financial and credit confidence, and therefore there is a "need to develop and implement strategic and tactical measures to ensure successful market activity in a rapidly changing environment" [5].

Effective equity management involves not only the assessment of financial stability and its role in ensur- ing the stability of the enterprise, but also the choice of the optimal structure of equity in terms of forming the required amount of equity of the enterprise [6]. We share the opinion of Silakova G.V. and Petukhova O.M., that the management of equity is an integral part of the financial management of the enterprise, which provides a justification of its sufficiency in accordance with the volume, structure and content of production activities; selection of the optimal method of capital accumulation (profit and issue of shares) in the current conditions, accounting for value and risks.In our opinion, when forming the system of equity management of the enterprise there is a need to take into account its components, principles, information support, functional subsystems (Fig. 3).

\section{Capital management is the management of the structure and value of sources of financing (liabilities) in order to increase the return on equity and the ability of the enterprise to pay in come to creditors and co- owners of the enterprise.}

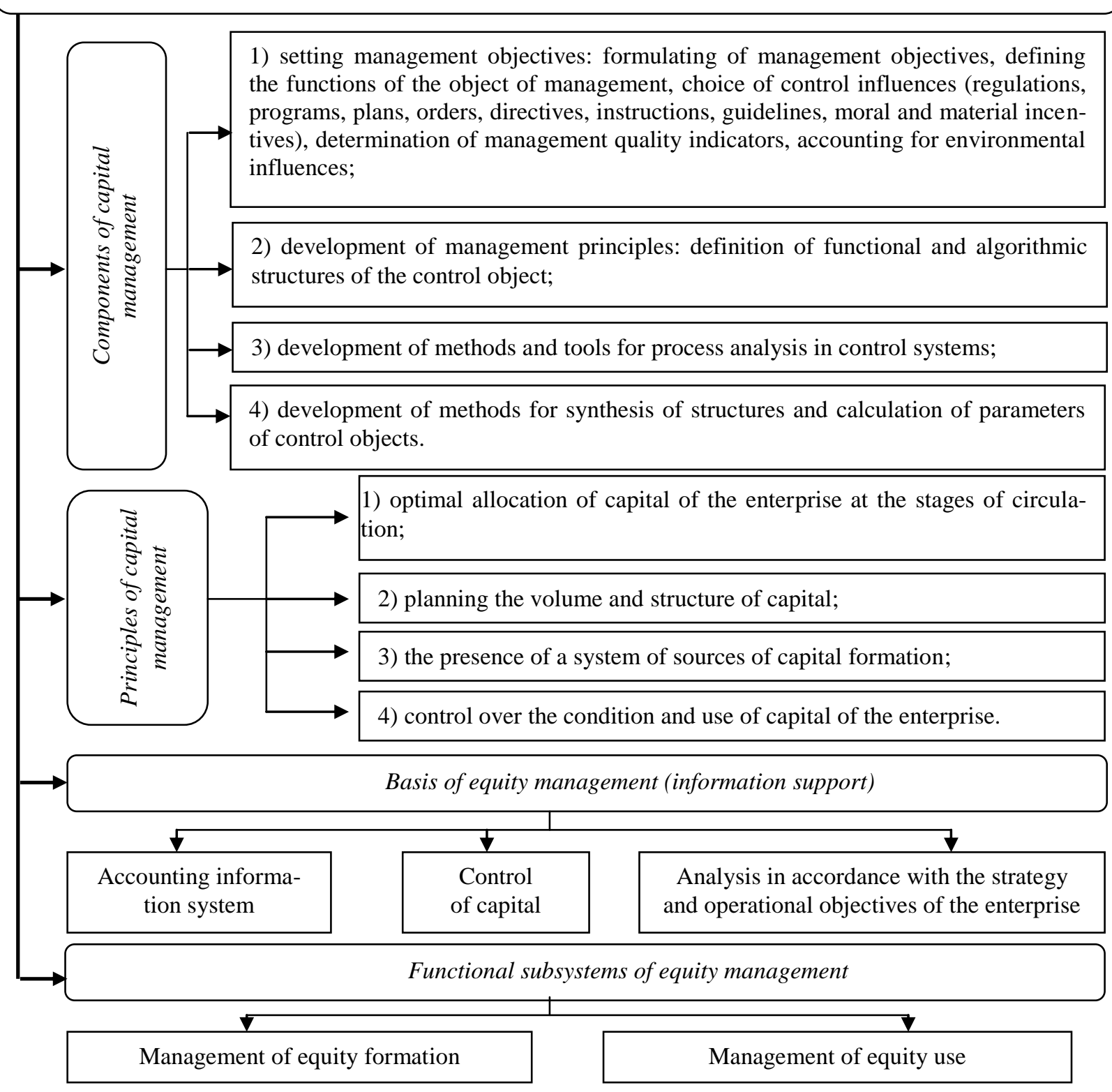

Fig. 3. Theoretical aspects of the equity management system of the enterprise* *compiled by author based on sources $[7,8]$ 
It should be noted that in order to make optimal management decisions at a modern enterprise, it is necessary to constantly evaluate important indicators of its activity, including indicators of the management system of capital formation and use [9].

According to the authors [6], the main purpose of equity management is to ensure and maintain capital adequacy. Sufficiency indicator, as evidenced by the practical activities of Ukrainian enterprises is different, as it is influenced by factors: the specifics of the economic activity of the enterprise, the phase of rise or fall of business activity, stability of turnover in the economic process, the ratio between fixed and variable costs, strategic orientation, the reputation of the enterprise in the eyes of borrowers, the composition of the property of the enterprise, etc. [5]. And to achieve the goal of effective equity management, should be adhered to and performed the tasks of equity management of the enterprise (Fig. 4).

\begin{tabular}{|c|c|}
\hline \multirow{9}{*}{ 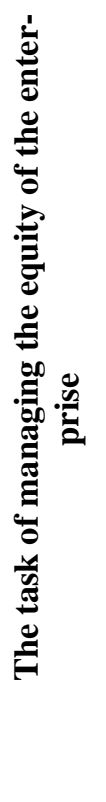 } & Determining the total need for capital to finance the activities of the enterprise \\
\hline & Choosing the most effective sources of capital attraction \\
\hline & Creating an information base for analysis and evaluation \\
\hline & $\begin{array}{l}\text { Optimization of the capital structure of the enterprise in accordance with the goals and } \\
\text { objectives of the activity }\end{array}$ \\
\hline & Implementation of a comprehensive assessment of equity \\
\hline & $\begin{array}{l}\text { Determining the compliance of equity formation with the requirements of domestic leg- } \\
\text { islation, the principles of stability, reliability }\end{array}$ \\
\hline & Formation of final judgments and opinions about the capital of the enterprise \\
\hline & Assessment of equity performance of its functions \\
\hline & Analysis of the effectiveness of management decisions \\
\hline
\end{tabular}

Fig. 4. The task of managing the equity of the enterprise*

*compiled by author based on sources [6]

"One of the most important problems faced by joint stock companies is the lack of efficiency in the organization of equity management in a financial crisis," said Kharchenko N.V. [10]. That is, the definition of a system of effective equity management in a newly created or existing enterprise is a prerequisite and guarantee of stable development of financial and economic activities.

As a result of research of literature sources, we offer five stages of the system of effective capital management:

1. Management of the process of equity formation.

2. Formation of a system of effective assessment of equity.

3. Determining the optimal structure of equity.

4. Management of the process of using equity.

5. Management of the process of maintaining and increasing equity.

Conclusions and prospects of the further investigations. As a result of the study of literature sources it is determined that the concept of "equity" is justified from the standpoint of economic, accounting, legal and financial management, and the purpose of equity formation is to meet the need to acquire necessary non- current and current assets and optimize its structure use and accumulation.

The analysis of the dynamics and structure of the balance of enterprises by type of economic activity of Ukraine for six years shows an improvement of the result by $90 \%$. It has been determined that during 2013-2018 the structure of the balance sheet asset has a stable ratio of current and non-current assets, while the analysis of the structure of liabilities of the balance sheet of enterprises by type of economic activity of Ukraine shows that the most part are current liabilities and provisions, and equity occupies the second position in the structure of the balance sheet and its share varies in the range of $24 \%$ $34 \%$, and long-term liabilities and provisionsoccupy the fifth part in the structure of sources of financing the assets of enterprises of Ukraine.

It has been determined that the economic crisis of 2014 significantly affected the change in the structure of equity of Ukrainian enterprises, and the uncovered loss, which has a negative upward trend, prompted the need for effective equity management, as this component increases equity and expands volumes of economic activity.

The identified theoretical aspects of the equity management system of the enterprise, which take into 
account the principles, subsystems, information support, tasks are the basis of the stages of the system of effective equity management, which has been developed and proposed.

During the study, we concluded that the general characteristics of the dynamics and structure of equity of enterprises by type of economic activity of Ukraine does not meet theoretical standards, as evidenced by the economic situation in most enterprises of Ukraine. Therefore, an equity management system is needed, which includes, in particular, the stage of "forming a system of effective valuation of equity" to rationally control it and prevent significant negative fluctuations that cause loss, insolvency, illiquidity, bankruptcy.

\section{References}

1. Kalinina, A. V., \& Dekhtiar, N. A. (2012). Pidkhody do upravlinnia vlasnym kapitalom pidpryiemstva. Molodizhnyi naukovyi visnyk UAVS NBU, (2), 132-144.

2. Slav'iuk, R. A. (2016). Kapital pidpryiemstv i bankiv: teoretychni osnovy formuvannia ta upravlinnia. Kyiv: DVNZ «Universytet bankivskoi spravy».

3. Vlasnyi kapital pidpryiemstv za vydamy ekonomichnoi diialnosti. Derzhavna sluzhba statystyky Ukrainy. Retrieved May 6, 2020, from http://www.ukrstat.gov.ua

4. Kudina, I. O., \& Starchenko, O. S. (2017). Vlasnyi kapital pidpryiemstva yak ekonomichna katehoriia ta yoho oblik. Pryazovskyi ekonomichnyi visnyk, (5(05)), 346-351.

5. Mashlii, H., \& Mosii, O. (2012). Model upravlinnia kapitalom pidpryiemstva ta suchasni tendentsii yoho formuvannia. Halytskyi ekonomichnyi visnyk, (1(34)), 43-49.

6. Silakova, H. V., \& Pietukhova, O. M. (2018). Suchasni pohliady na upravlinnia vlasnym kapitalom pidpryiemstva. Intelekt KhKhI, (3), 101-105.

7. Mishchuk, Ye. V., \& Mishchenko, V. V. (2015). Osoblyvosti systemy upravlinnia vlasnym kapitalom pidpryiemstva ta shliakhy yii vdoskonalennia. Ahrosvit, (24), 46-49.

8. Kirsanova,T. O., \& Koliada, N. O. (2010). Systema upravlinnia vlasnym kapitalom pidpryiemstva. Visnyk SumDU, (1), 58-63.

9. Markova, T. D., \& Stupnytska, M. I. (2020). Pidkhody do otsinky vlasnoho kapitalu pidpryiemstva: teoretychnyi aspekt. In Suchasni tekhnolohii menedzhmentu, informatsiine, finansove ta oblikove zabezpechennia rozvytku ekonomiky $v$ umovakh yevrointehratsii (pp. 257-259). Cherkasy : Skhidnoievropeiskyi universytet ekonomiky i menedzhmentu.

10. Kharchenko, N. V. (2011). Otsinka efektyvnoho upravlinnia vlasnym kapitalom aktsionernoho tovarystva. Investytsii: praktyka ta dosvid, (17), 44-47.

Received 5 May2020

Approved 19 May 2020

Available in Internet 11.07.2020

Куприна Н.M.

кандидат экономических наук, доцент кафрдра учета и аудита E-mail:k.natali@ukr.net ORCID ID: 0000-0003-4645-545X
Маркова Т.Д.

кандидат экономических наук, доцент кафедра учета и аудита

E-mail: markova.tetiana17@gmail.com

ORCID ID: 0000-0002-9437-2635

\section{Ступницкая М.И.}

студентка 4 курса фракультета менеджмента, маркетинга и логистики Одесская национальная академия пищевых технологий ул. Канатная, 112, г. Одесса, Украина, 65039 E-mail: marino4ka036@gmail.com ORCID ID: 0000-0003-0736-6411

\section{АНАЛИЗ СОБСТВЕННОГО КАПИТАЛА ПРЕДПРИЯТИЙ УКРАИНЫ И ОСОБЕННОСТИ УПРАВЛЕНИЯ ИМ В УСЛОВИЯХ НОВОЙ ЭКОНОМИКИ ГЛОБАЛЬНОГО РЫНКА}

В статье отмечается, что понятие «собственный капитал» в рассмотренных литературных источниках рассматривается с позиции экономической, учетной, юридической и финансового менеджмента. Обосновывается, что собственный капитал предприятия является основой финансового формирования активов и финансово-хозяйственной деятельности предприятия. Проведенный анализ ди- 
намики и структуры баланса Украины за пять лет свидетельствует об увеличении валюты баланса на 90\%. Определено, что структура актива баланса имеет стабильное соотношение оборотных и необоротных активов в течение 2013-2018 гг. Анализ структуры пассива баланса показывает, что наибольшую часть составляют текущие обязательства и обеспечения, собственный капитал занимает второе место в структуре баланса и его удельный вес колеблется в диапазоне $24 \%-34 \%$. Долгосрочные обязательства и обеспечения занимают до $22 \%$ источников формирования активов предприятий Украины.

Проведенный анализ статистической динамики изменения структуры собственного капитала предприятий Украины за пять лет, свидетельствует, что с 2014 года резко изменилась структура именно зарегистрированного капитала, дополнительного капитала и появился непокрытый убыток, который имеет негативную тенденцию к увеличению. Низкое значение нераспределенной прибыли и появление ущерба обосновывает необходимость системы эффективного управления собственным капиталом, поскольку именно за счет этой составляющей происходит увеличение собственного капитала и расширение объемов хозяйственной деятельности. Определены задачи для эффективного управления собственным капиталом. Предложено этапы системы эффективного управления собственным капиталом.

Ключевые слова: собственный капитал, структура собственного капитала предприятия, анализ, управление, баланс.

Купріна Н.M.

кандидат економічних наук, доцент кафедра обліку та аудиту E-mail:k.natali@ukr.net ORCID ID: 0000-0003-4645-545X
Маркова Т.Д.

кандидат економічних наук, доцент кафедра обліку та аудиту

E-mail: markova.tetiana17@gmail.com

ORCID ID: 0000-0002-9437-2635

\section{Ступницька М.I.}

студентка 4 курсу фракультету менеджменту, маркетингу та логістики

Одеська національна академія харчових технологій

вул. Канатна 112, м. Одеса, Україна, 65039

E-mail: marino4ka036@ gmail.com

ORCID ID: 0000-0003-0736-6411

\section{АНАЛІЗ ВЛАСНОГО КАПІТАЛУ ПІДПРИЄМСТВ УКРАЇНИ ТА ОСОБЛИВОСТІ ЙОГО УПРАВЛІННЯ В УМОВАХ НОВОЇ ЕКОНОМІКИ ГЛОБАЛЬНОГО РИНКУ}

У статті зазначається, що поняття «власний капітал» в досліджених літературних джерел розглядається з позиції економічної, облікової, юридичної та фрінансового менеджменту. Обґрунтовується, що власний капітал підприємства $€$ підґрунтям фрінансового формування активів та фінансовогосподарської діяльності підприємства. Проведений аналіз динаміки та структури балансу України за п'ять років свідчить про збільшення валюти балансу на 90\%. Визначено, що структура активу балансу має стабільне співвідношення оборотних та необоротних активів протягом 2013-2018 рр. Аналіз структури пасиву балансу демонструє, що найбільшу частину складають поточні зобов'язання і забезпечення, власний капітал займає друге місце в структурі балансу і його питома вага коливається в діапазоні 24\%-34\%. Довгострокові зобов'язання і забезпечення охоплюють до 22\% джерел формування активів підприємств Україні.

Проведений аналіз статистичної динаміки зміни структури власного капіталу підприємств України за п'ять років, свідчить, що з 2014 року різко змінилась структура саме зареєстрованого капіталу, додаткового капіталу та з'явився непокритий збиток, який має негативну тенденцію до збільшення. Низьке значення нерозподіленого прибутку та поява збитку обґрунтовує необхідність системи ефективного управління власним капіталом, оскільки саме за рахунок цієї складової відбувається збільшення власного капіталу та розширення обсягів господарської діяльності. Визначено завдання для ефективного управління власним капіталом. Запропоновано етапи системи ефективного управління власним капіталом. ня, баланс.

Ключові слова: власний капітал, структура власного капіталу підприємства, аналіз, управлін- 


\section{Література}

1.Калініна А.В., Дехтяр Н.А. Підходи до управління власним капіталом підприємства // Молодіжний науковий вісник УАВС НБУ. Серія: Економічні науки. 2012. №2. С.132-144.

2. Слав'юк Р.А. Капітал підприємств і банків: теоретичні основи формування та управління: монографія. К.: ДВНЗ «Університет банківської справи», 2016. 330 с.

3. Власний капітал підприємств за видами економічної діяльності // Державна служба статистики України. URL: http://www.ukrstat.gov.ua (дата звернення 06.05.2020).

4. Кудіна I.О., Старченко О.С. Власний капітал підприємства як економічна категорія та його облік // Приазовський економічний вісник. 2017. Вип. 5(05). С. 346-351.

5. Машлій Г., Мосій О. Модель управління капіталом підприємства та сучасні тенденції його формування // Галицький економічний вісник. 2012. №1(34). С.43-49.

6. Сілакова Г.В., Пєтухова О.М. Сучасні погляди на управління власним капіталом підприємства. Інтелект XXI. 2018. № 3. С.101-105.

7. Міщук Є.В., Міщенко В.В. Особливості системи управління власним капіталом підприємства та шляхи її вдосконалення // Агросвіт. 2015. № 24. С.46-49.

8. Кірсанова Т.О., Коляда Н.О. Система управління власним капіталом підприємства // Вісник СумДУ. Серія економіка. 2010. № 1. С. 58-63.

9. Маркова Т. Д., Ступницька М. І. Підходи до оцінки власного капіталу підприємства: теоретичний аспект // Сучасні технології менеджменту, інформаційне, фінансове та облікове забезпечення розвитку економіки в умовах євроінтеграції: збірник тез доповідей учасників Всеукраїнської науково-практичної конференції, м. Черкаси, 16-17 квітня 2020 року. Черкаси : Східноєвропейський університет економіки і менеджменту, 2020. 557 с. (С.257-259).

10. Харченко Н.В.Оцінка ефективного управління власним капіталом акціонерного товариства // Інвестиції: практика та досвід. 2011. № 17. С. 44-47.

Стаття надійшла 5.05.2020

Стаття прийнята до друку 19.05.2020

Доступно в мережі Internet 11.07.2020

Цитування згідно ДСТУ 8302:2015

Kuprina N., Markova T., Stupnytska M. Analysis of the own capital of Ukrainian enterprises and features of its management in the conditions of the new economy of the global market // Food Industry Economics. 2020. Vol.12, Issue 2. P. 30-37. doi: 10.15673/fie.v12i2.1737

Cite as APA style citation

Kuprina, N., Markova, T., \& Stupnytska, M. (2020). Analysis of the own capital of Ukrainian enterprises and features of its management in the conditions of the new economy of the global market. Food Industry Economics, 12(2), 30-37. doi: 10.15673/fie.v12i2.1737 